\title{
Glucocorticoids Increase the Synthesis of Immunoglobulin E by Interleukin 4-stimulated Human Lymphocytes
}

C. Y. Wu, M. Sarfati, C. Heusser, ${ }^{\star}$ S. Fournier, M. Rubio-Trujillo, R. Peleman, and G. Delespesse

Research Center, Notre-Dame Hospital, University of Montreal, Montreal, Canada H2L 4MI;

and ${ }^{*}$ Ciba-Geigy Pharmaceuticals, Basel, Switzerland

\begin{abstract}
This study indicates that hydrocortisone (HC) markedly increases the synthesis of immunoglobulin $\mathrm{E}$ (IgE) by interleukin 4 (IL-4)-stimulated human lymphocytes. The effect is glucocorticoid specific and is obtained with low concentrations of $\mathrm{HC}$ (0.1-10 $\mu \mathrm{M})$. In both the early and the late phase of the IL-4induced response $\mathrm{HC}$ exerts its effects which are respectively IL-4 dependent and IL-4 independent. The IgE potentiation cannot be explained by the inhibition of interferon- $\gamma$ (IFN- $\gamma$ ) production since it is observed in the absence of endogenous secretion of IFN- $\gamma$. HC inhibits the production of IgE-binding factors (soluble CD23) and the expression of the low-affinity receptor for IgE, also known as the (FceRII) CD23 antigen; however, the residual expression of FceRII by IL-4- and HCtreated peripheral blood mononuclear cells (PBMCs) is important since the IgE response of these cells is markedly inhibited by anti-CD23 monoclonal antibody. HC acts mainly by amplifying the cellular interactions between monocytes and lymphocytes; indeed, HC has no effect on monocyte-depleted PBMCs, and moreover, monocytes cannot be replaced by soluble factors. Most importantly, $\mathbf{T}$ cells are not required for the induction of IgE synthesis by costimulation with IL-4 and HC. However, the IgE response of rigorously $T$ cell-depleted PBMCs may be further increased by the addition of $T$ cells. Further analysis of the permissive effect of $\mathrm{HC}$ on the synthesis of $\mathrm{IgE}$ by $\mathrm{T}$ celldepleted PBMCs suggests that $\mathrm{HC}$ acts in synergy with $\mathrm{IL}-4$ to trigger the activation and the differentiation of $B$ cells into IgEproducing cells. (J. Clin. Invest. 1991. 87:870-877.) Key words: CD23 antigen • estradiol $\bullet$ interferon- $\gamma \cdot$ progesterone • testosterone
\end{abstract}

\section{Introduction}

Glucocorticoids (GCs) ${ }^{1}$ are widely used as anti-inflammatory, immunosuppressive, and antiallergic agents. Their mode of action is very complex since they act at the various steps of the

Address reprint requests to Dr. Delespesse, University of Montreal, Notre-Dame Hospital Research Center, 1560 Sherbrooke Street East, Montreal, Quebec, H2L 4M1 Canada.

Received for publication 30 April 1990 and in revised form 27 September 1990

1. Abbreviations used in this paper: CLL, chronic lymphocytic leukemia; CSN, culture supernatant; Fc $\epsilon$ RII, low-affinity receptor of IgE, also known as CD23 antigen; GCs, glucocorticoids; HC, hydrocortisone; IgE-BFs, IgE-binding factors or soluble CD23; sCD23, soluble CD23 antigen.

J. Clin. Invest.

(C) The American Society for Clinical Investigation, Inc.

0021-9738/91/03/0870/08 \$2.00

Volume 87, March 1991, 870-877 immune response and of the subsequent inflammatory reaction. In addition to a direct effect on immunocompetent cells, GCs markedly influence the migration of leukocytes, the release of inflammatory mediators and the response to these mediators $(1,2)$. Most studies concur to demonstrate that GCs suppress cell-mediated immune responses whereas their effect on $\mathbf{B}$ cell function is more variable $(1,3,4)$. The production of polyclonal Ig is significantly increased in the presence of GCs in vitro (5-7). Moreover, as recently reported, GC treatment may differently affect the in vivo IgG and IgA antibody response (8). Treatment of allergic patients with GCs has either no effect or increases the serum IgE levels in spite of clinical improvement (9-11). The effect of GCs on the in vitro synthesis of human IgE has not been documented with the exception of two conflicting studies that examined the influence of GCs on the spontaneous synthesis of IgE by lymphocytes from allergic patients $(12,13)$. Very recently, Sarfati et al. (14) reported, that upon stimulation with both interleukin 4 (IL-4) and hydrocortisone (HC), the peripheral blood mononuclear cells (PBMCs) of patients with chronic lymphocytic leukemia (CLL) could be induced to synthesize monoclonal IgE. The IgE response of the B cells of CLL patients was strictly dependent upon the presence of $\mathrm{HC}$; indeed in contrast to normal lymphocytes, the PBMCs of CLL patients did not produce any IgE in response to IL-4 alone. In this study we report that HC strongly increases the in vitro synthesis of IgE by IL-4-stimulated human lymphocytes. The analysis of the cellular mechanisms indicates that the IgEpotentiating effect of $\mathrm{HC}$ is strictly monocyte dependent. However and most interestingly, the IgE synthesis induced by costimulation with IL-4 and HC does not require the presence of $\mathrm{T}$ cells.

\section{Methods}

\section{Reagents}

$\mathrm{HC}$, testosterone, $\beta$-estradiol, progesterone (all from Sigma Chemical Co., St. Louis, MO), and the high-affinity anticorticosteroid RU38486 (kindly provided by Dr. J. P. Pelletier, Notre-Dame Hospital, Montreal) were dissolved in ethanol and stored at $-20^{\circ} \mathrm{C}$. They were diluted in culture medium immediately before use. This resulted in ethanol concentrations in the cultures of $<0.01 \%$. In control experiments, these concentrations of ethanol had no measurable effect on the secretion of IgE and of IgE-binding factors (IgE-BFs), or soluble $\mathrm{CD} 23$ (sCD23). In some experiments, water-soluble $\mathrm{HC}$ sodium succinate (Upjohn Co., Kalamazoo, MI) was used instead of $\mathrm{HC}$ acetate. The monoclonal antibody (MAb) to the low-affinity receptor for IgE (Fc $\epsilon$ RII), also known as CD23 antigen (MAb 135), and the isotype-matched control MAb (against LolpI, a grass pollen allergen) have been described previously (15). The neutralizing mouse MAb to human IL-4 $(\mathrm{IgG}, \mathrm{K})$ is the same as that used in a previous work (16); its 
production and characterization will be reported separately. Recombinant human IL-4 was obtained from Genzyme Corp., Boston, MA; HB101 culture medium was from Hana Biologies, Inc., Berkeley, CA. RPMI 1640 culture medium, fetal calf serum (FCS), penicillin, and streptomycin were purchased from Flow Laboratories, Rockville, $\mathrm{MD}$. $\mathrm{MO}_{2} \mathrm{MAb}$ (against CD14A8) was obtained from Beckton-Dickinson, Mountain View, CA.

\section{Mononuclear cell preparation and culture conditions}

PBMCs were isolated from the heparinized blood of healthy volunteers by density gradient centrifugation on Sepracell-MN (Sepratech Co., Oklahoma City, OK) according to the instruction manual. For monocyte depletion, PBMCs were applied on a second Sepracell MN gradient from which two fractions were collected, i.e., monocyte depleted and monocyte enriched. Cells from the monocyte-depleted fractions (which still contained 2-5\% MO2-positive cells) were washed and incubated for $45 \mathrm{~min}$ at room temperature with $4 \mathrm{mM}$ L-leucine methyl ester (Sigma Chemical Co.) in Hepes-buffered RPMI 1640 culture medium as described (17). The resulting cells contained no detectable MO2-positive cells. Adherent cells were isolated from the monocyte-enriched fraction by adherence to plastic dish. To this end, cells were resuspended in $5 \mathrm{ml}$ of RPMI 1640 medium supplemented with $10 \%$ FCS $\left(3 \times 10^{6}\right.$ cells $\left./ \mathrm{ml}\right)$ and incubated for $45 \mathrm{~min}$ at $37^{\circ} \mathrm{C}$ in a $100 \times 15-\mathrm{mm}$ plastic dish (Nunclon Delta SI, Gibco/BRL, Burlington, Ontario). Adherent cells were collected by incubation of the flask for $15 \mathrm{~min}$ at $4^{\circ} \mathrm{C}$ with cold PBS containing $1 \mathrm{mM}$ EDTA, pH 7.2, followed by vigorous washing of the adherence surface by repeated pipetting of the PBS-EDTA solution. After washing twice with HBSS, $>80 \%$ of the resulting cells were MO2 positive. T celldepleted PBMCs were prepared by two-cycle rosetting with 2aminoethylisothiouronium bromide-treated sheep red blood cells (SRBC) and by separating the rosette-forming cells on Ficoll-Metrizoate gradient. The residual $T$ cells were further removed by means of anti-CD3-coated magnetic beads (Dynabeads M-450, Dynal Inc., Great Neck, NY) according to the instruction manual. Briefly, the beads were coated with purified anti-CD3 MAb (OKT3, Ortho Pharmaceutical, Raritan, $\mathrm{NJ} ; 50 \mu \mathrm{g}$ of antibody for $4 \times 10^{8}$ beads), and reacted for $1 \mathrm{~h}$ with the $\mathrm{T}$ cell-depleted preparation (assumed to contain 5\% residual CD3-positive cells) at a bead/target cell ratio of 40:1. After removal of the Dynabeads with a magnet, the resulting cells contained no CD3-positive cells.

Cells were cultured at the concentration of $1.5 \times 10^{6}$ cells/ $\mathrm{ml}$ in HB101 culture medium supplemented with $5 \mathrm{mM}$ L-glutamine, $5 \%$ FCS, 50 IU penicillin, and $50 \mu \mathrm{g} / \mathrm{ml}$ streptomycin. Cultures were carried out in a $1-\mathrm{ml}$ volume in 48 -well tissue culture plates (Costar Data Packaging, Cambridge, MA) for a period of 12-14 d. In all the experiments reported in this study, IL-4 was used at $10 \mathrm{ng} / \mathrm{ml}$, which was found to be optimal in our culture conditions.

\section{Analysis of CD23 expression}

Fc $\epsilon$ RII/CD23 expression was detected by indirect immunofluorescence analysis using flow cytometry. Briefly, $1 \times 10^{6}$ cells were washed twice in PBS, supplemented with $3 \%$ (wt/vol) BSA and $0.1 \%$ sodium azide (PBN). Cell pellets were incubated overnight on ice, with $50 \mu$ l of biotinylated anti-CD23 MAb 208.25.A.3/135 (MAb 135) at a final concentration of $3 \mu \mathrm{g} / \mathrm{ml}$. This MAb recognizes the low-affinity FceRII on monocytes, B and $T$ lymphocytes. As a negative control, the cells were incu- bated with $50 \mu$ l of a biotinylated unrelated isotype matched mouse MAb (anti-Lol P1) of the same subclass (IgG1, K). In all samples, $50 \mu \mathrm{l}$ of normal human $\operatorname{IgG}(300 \mu \mathrm{g} / \mathrm{ml})$ was added to prevent passive adsorption of the MAb on Fc $\gamma$ R. Cells were then washed three times in PBN and incubated for $30 \mathrm{~min}$ in the dark at $4^{\circ} \mathrm{C}$ with $25 \mu$ l of FITC-conjugated avidin. After two washes in PBN and one in PBS-azide, cells were resuspended in $1 \mathrm{ml}$ of PBS-azide and analyzed by using a FAC$\mathrm{Scan}^{\circledR}$ and C30 software (Becton, Dickinson \& Co.). CD3-positive cells were detected by staining with FITC-conjugated Leu 4; an FITC-mouse IgG was used as negative control; monocytes were identified by using FITC-Leu M3 and one FITCmouse IgG2b as negative control (all from Becton, Dickinson \& Co.).

\section{Radioimmunoassays}

Measurement of Ig. These assays were performed as described previously (18). Briefly, 96-well polyvinyl microtiter plates (Dynatech Laboratories, Inc., Alexandria, VA) were coated with either mouse MAb specific to human IgE (clone 89) or with IgG fraction of sheep antisera specific to $\alpha, \gamma$, or $\mu$ chains. After a 2-h blocking with Hanks' supplemented with FCS, the samples (75 $\mu$ l of buffered culture supernatant [CSN]) were incubated overnight at room temperature in a humid atmosphere. The wells were then washed and reacted overnight with $75 \mu$ l of radiolabeled, affinity-purified antibodies to human $\mu$, $\gamma$, or $\alpha$ chains or with MAb to human IgE (clone 4.15, a gift from Dr. A. Saxon, University of California at Los Angeles, Los Angeles, CA). The results are expressed as the net Ig synthesis, obtained after subtraction of the Ig levels measured in cycloheximide-treated parallel cultures. The IFN- $\gamma$ levels in cell-free CSNs were determined by a commercially available solid-phase radioimmunoassay (RIA) kit (Centocor Co., Malvern, PA).

I $g E$-BFs. IgE-BFs were measured by a solid-phase RIA as described previously (19). Briefly, 96-well microtiter plates

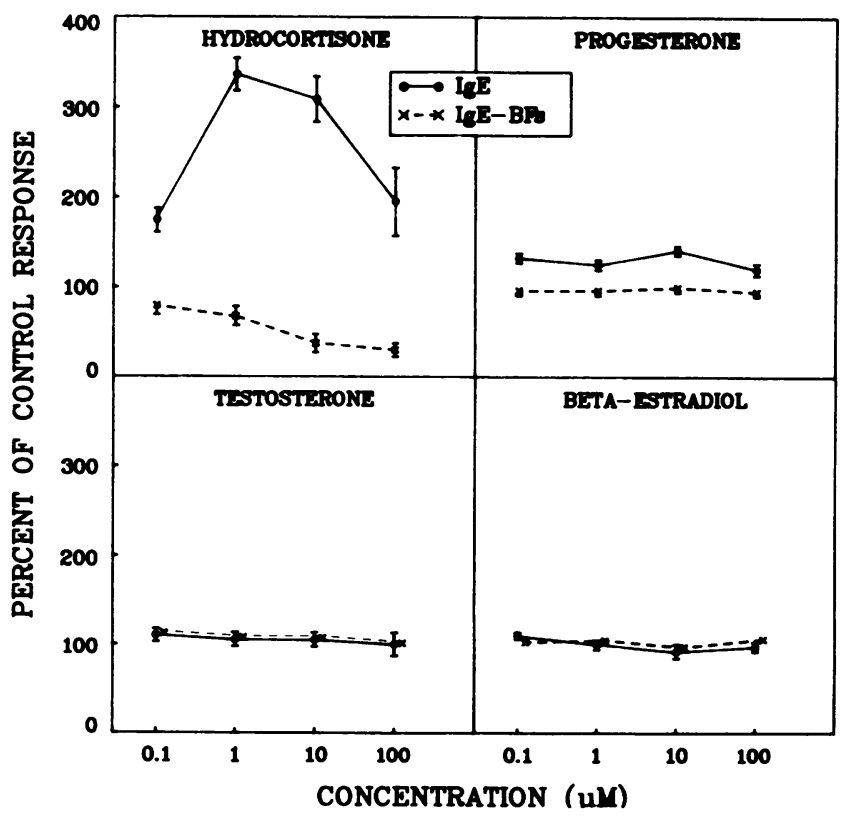

Figure 1. Effect of steroid hormones on IgE and IgE-BF production by IL-4-stimulated PBMCs from four normal donors. Results are expressed in percentage (mean \pm 1 SEM) of the response to IL- 4 alone which was of $20 \pm 3.2 \mathrm{ng} / \mathrm{ml}$ of IgE and $360 \pm 27 \mathrm{U} / \mathrm{ml}$ of IgE-BFs. 


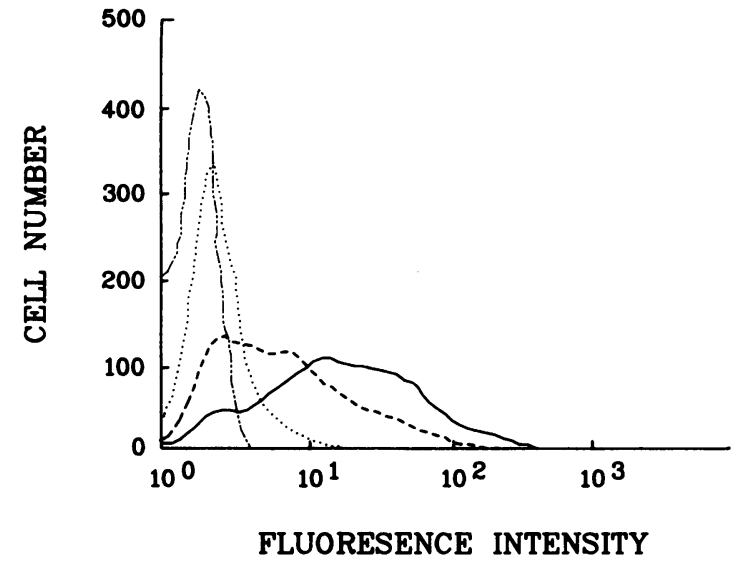

Figure 2. Effect of HC on FceRII expression by IL-4-stimulated tonsillar B lymphocytes. Cells $\left(1 \times 10^{6} / \mathrm{ml}\right)$ were cultured $48 \mathrm{~h}$ as indicated, washed, and analyzed by flow cytometry. Shown is the expression of Fc $\in$ RII on unstimulated cells $(\cdots)$ or IL-4-stimulated cells in the absence (-) or in the presence of $10 \mu \mathrm{M}$ HC (---). Also shown is the autofluorescence determined by an isotype-matched unrelated mouse MAb $(\cdot \cdot \cdot)$.

were coated with $100 \mu \mathrm{l}$ of anti-CD23 MAb 176 at a concentration of $15 \mu \mathrm{g} / \mathrm{ml}$. After overnight incubation, plates were blocked for $2 \mathrm{~h}$ with Hanks' supplemented with FCS, and after washing, $75 \mu \mathrm{l}$ of the sample was allowed to incubate for $4 \mathrm{~h}$. The plates were then washed and $75 \mu$ of ${ }^{125}$ I-anti-CD23 MAb $135\left(2-3 \times 10^{4} \mathrm{cpm} / \mathrm{ng}\right)$ was added to the wells. After overnight incubation, the wells were washed and counted in a gamma counter. The total radioactivity was $\pm 300,000 \mathrm{cpm} /$ well and the blank was determined by H-FCS $( \pm 160 \mathrm{cpm})$.

\section{Measurement of $\left[{ }^{3} \mathrm{H}\right]$ thymidine incorporation}

Cells $\left(3 \times 10^{5}\right.$ cells in $0.2 \mathrm{ml}$ of culture medium) were cultured in four replicates in 96-well flat-bottom plate (catalogue no. 3599, Costar Data Packaging) for the indicated periods of time. $6 \mathrm{~h}$ before harvesting, $0.1 \mathrm{ml}$ of CSN was collected from each well (for the measurement of IgE) and replaced by culture medium containing $1 \mu \mathrm{Ci}$ of $\left[{ }^{3} \mathrm{H}\right]$ thymidine (sp act $2 \mu \mathrm{Ci} / \mathrm{mmol}$; Amersham Corp., Arlington Heights, IL). Cells were collected by a cell harvester (Cambridge Technology, Cambridge, MA) and the radioactivity (counts per minute) was counted in scintillation fluid Econofluor (New England Nucleur, Boston, MA).

\section{Results}

$H C$ potentiates the synthesis of IgE by IL-4-stimulated PBMC. The synthesis of IgE by IL-4-stimulated PBMCs is significantly increased in the presence of $0.1-10 \mu \mathrm{M}$ HC (Fig. 1). At optimal concentrations ( 1 or $10 \mu \mathrm{M}$ ) the IgE-potentiating effect of $\mathrm{HC}$ is constant but its magnitude is highly variable (from 2- to 100 -fold increase) as determined in a very large number of experiments. At $100 \mu \mathrm{M}$, the effect of $\mathrm{HC}$ is irregular and in some cases the IgE response is suppressed. Although the data are not shown, it is of note that $\mathrm{HC}$ significantly increases the production of IgA but not of IgG or IgM by IL-4-stimulated PBMCs. In the absence of IL-4, HC does not elicit IgE synthesis whereas, as expected (7), it augments the production of all the other Ig classes. As seen, other steroid hormones, including testosterone, progesterone, and estradiol, do not influence the synthesis of IgE. These data suggesting that the IgE-potentiating activity of $\mathrm{HC}$ is glucocorticoid specific are supported by two additional observations: $(a)$ it is inhibited by $70-80 \%$ in the presence of equimolar concentrations of RU38486, a potent inhibitor of steroid hormone receptors; $(b)$ dexamethasone, a glucocorticoid analogue binding to $\mathrm{GC}$ receptor with an affinity 20 times greater than that of $\mathrm{HC}$ is also at least 10 times more active than $\mathrm{HC}$ in potentiating IgE synthesis (not shown).

Role of FceRII or of its soluble fragments in the IgE-potentiating effect of $H C$. Since FceRII or its soluble IgE-binding fragments (IgE-BFs) were shown to play a role in the IL4-induced synthesis of IgE (20-22), we have examined the effect of $\mathrm{HC}$ on the expression of these molecules by IL-4-stimulated PBMCs. HC significantly inhibits both the release of IgE-BFs (Fig. 1) and the expression of FceRII (Fig. 2) by IL-4-stimulated lymphocytes; this effect is GC specific. At concentrations of 1 or $10 \mu \mathrm{M}$, which are optimal for potentiating IgE synthesis, HC suppresses the production of IgE-BFs by $40-70 \%$. The residual expression of Fc $\epsilon$ RII (and/or the release of its soluble fragments) is required for an optimal IgE response to IL-4 and HC. Indeed, the IgE response obtained in the presence of $\mathrm{HC}$ is markedly suppressed by anti-FceRII MAb but not by the isotype-matched control MAb (Fig. 3). In four such experiments, FceRII MAb $(1 \mu \mathrm{g} / \mathrm{ml})$ inhibited the IgE response to IL-4 alone by $60 \pm 15 \%$ and the IgE response to IL- $4+$ HC by $80 \pm 12 \%$.

$\operatorname{IgE}(\mathbf{n g} / \mathbf{m l})$

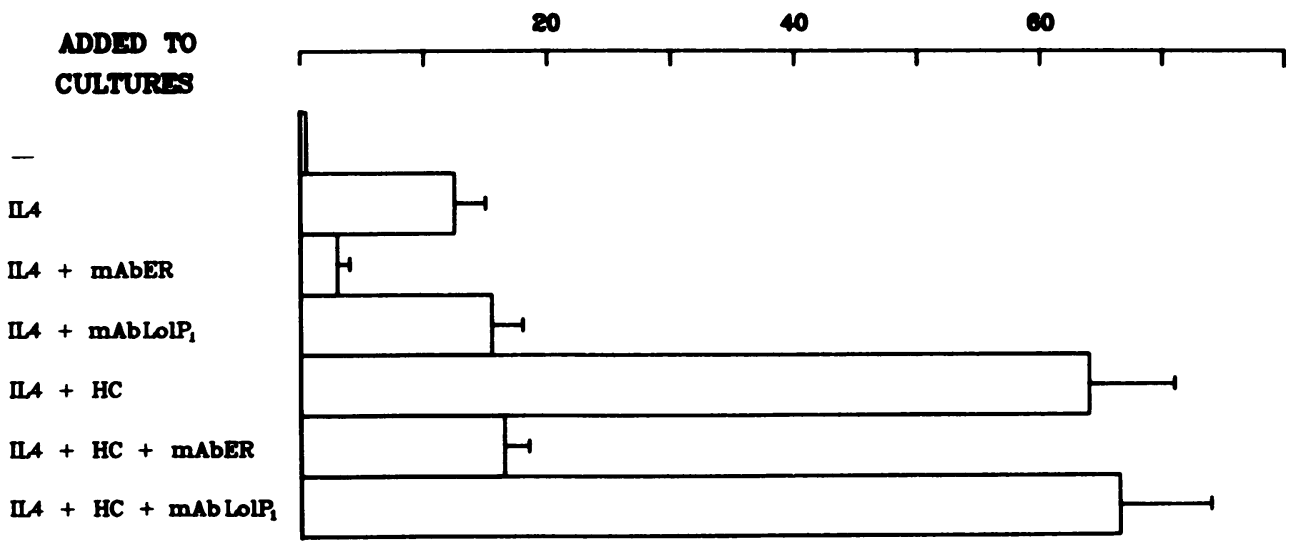

Figure 3. Effect of MAb against FceRII (MAb 135) on the synthesis of IgE by PBMCs stimulated with IL-4 or with IL-4 and $10 \mu$ MHC. MAbER 135 and the isotype-matched control $\mathrm{MAb}$ (anti-Lol pl, an antigen from Rye grass pollen) were used at $1 \mu \mathrm{g} / \mathrm{ml} ; \mathrm{HC}$ was used at 10 $\mu \mathrm{M}$. Shown are the mean values \pm 1 SD of three replicates, with one representative experiment out of four. 

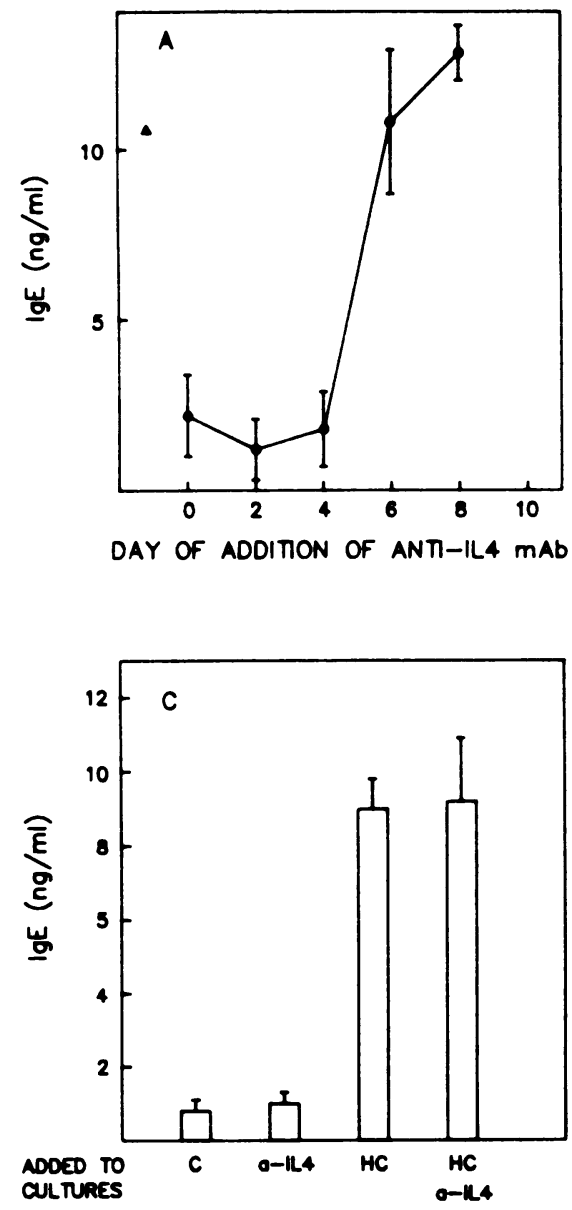
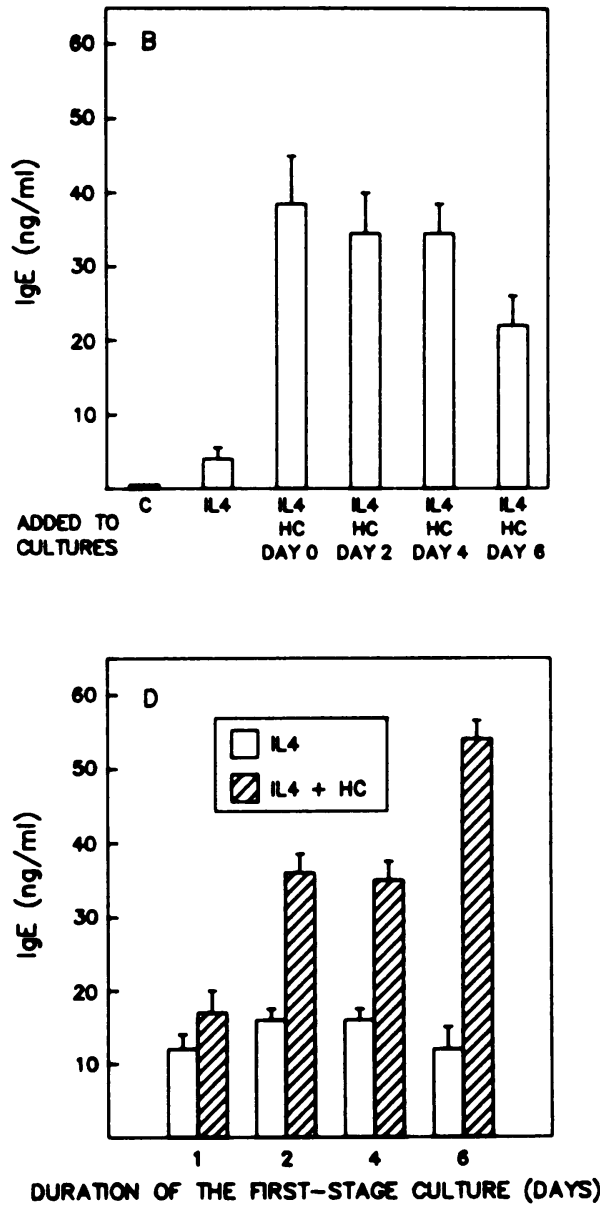

Figure 4. Kinetic studies. Delayed addition of $(A)$ antiIL-4 MAb $(10 \mu \mathrm{g} / \mathrm{ml})$ or $(B)$ $\mathrm{HC}(10 \mu \mathrm{M})$ to IL-4-stimulated cultures of PBMCs. In $A$, the solid triangle (A) refers to the control IgE response observed in the absence of anti-IL-4 MAb. (C) Secondary cultures where PBMCs have been preactivated for 1 wk with IL-4, washed, and cultured for another week in culture medium alone (column marked $C$ ) or in the presence of either anti-IL-4 $\mathrm{MAb}(10 \mu \mathrm{g} / \mathrm{ml}), \mathrm{HC}(10$ $\mu \mathrm{M})$, or both $\mathrm{HC}$ and antiIL-4 MAb. (D) Cells were first preincubated for the indicated periods either with IL-4 alone or with IL-4 and $\mathrm{HC}(10 \mu \mathrm{M})$, washed, and then recultured in the presence of IL-4 for a total culture period of $12 \mathrm{~d}$. In each case one representative of at least four experiments is shown; mean \pm 1 SD of triplicates.
$H C$ acts at multiple levels in the cellular interactions leading to the synthesis of I $E E$ by IL-4-stimulated PBMC. The data in Fig. $4 \mathrm{~A}$ indicate that a neutralizing MAb to IL-4 suppresses the IL-4-induced IgE synthesis only when added during the first 4 $\mathrm{d}$ of the 12-d culture; at day 6 or after, this antibody has no effect. In contrast, $\mathrm{HC}(10 \mu \mathrm{M})$ still increases the production of IgE when added at day 6 (Fig. $4 \mathrm{~B}$ ), suggesting that $\mathrm{HC}$ may still act during the IL-4-independent stage of the IgE response. This was confirmed in two-stage cultures where PBMCs are first incubated for $7 \mathrm{~d}$ with IL-4, extensively washed, and recultured for another week in the absence of IL-4. The addition of HC to the secondary cultures consistently increases IgE synthesis (Fig. $4 C$ ). The possible effect of HC during the early stage of the IL-4 stimulation was next examined in washout experiments. In these assays PBMC are first cultured for various periods of time with either IL-4 alone or with IL-4 and HC, the cells are then washed and recultured with IL-4 alone. As seen (Fig. $4 \mathrm{D}$ ), PBMCs exposed to both IL-4 and HC during the first $1-4 \mathrm{~d}$ of the culture produce more IgE than control cells exposed to IL-4 alone.

$H C$ potentiates the synthesis of IgE even in the absence of endogenous production of IFN- $\gamma$. An obvious explanation of the IgE-potentiating effect of $\mathrm{HC}$ is that it suppresses the production of IFN- $\gamma$ (3) a natural antagonist of IgE synthesis (22). However, additional mechanisms must also be involved since HC strongly increases the IgE response of neonatal lymphocytes which do not produce IFN- $\gamma$ when cultured in the absence of HC. In four such experiments, umbilical cord blood lymphocytes were cultured in culture medium alone or in the presence of either IL-4 or of IL-4 and HC. At day 4, $250 \mu$ l of $\mathrm{CSN}$ was collected for IFN- $\gamma$ measurement and replaced by fresh culture medium. IFN- $\gamma$ was not detectable in any of these cultures, whereas the mean $( \pm 1 \mathrm{SEM})$ values of $\mathrm{IgE}$ in these four experiments were $2.4 \pm 0.8 \mathrm{ng} / \mathrm{ml}$ for IL-4-stimulated cultures and $15.5 \pm 3.9 \mathrm{ng} / \mathrm{ml}$ for cultures stimulated with both IL-4 and $1 \mu \mathrm{M} \mathrm{HC}$.

Table I. IgE-potentiating Activity of $H C$

\begin{tabular}{|c|c|c|c|c|}
\hline \multirow{2}{*}{$\begin{array}{l}\text { Added to } \\
\text { cultures }\end{array}$} & \multicolumn{4}{|c|}{ IgE-potentiating activity in cells in culture } \\
\hline & PBMCs & MO-depleted* & MO-depleted $+\mathrm{MO}^{\ddagger}$ & $\mathrm{MO}^{\mathrm{s}}$ \\
\hline & \multicolumn{4}{|c|}{$n g / m l$} \\
\hline - & 0.1 & 0.2 & 0.2 & 0.1 \\
\hline II-4 & $8.7 \pm 1.2$ & $1.2 \pm 0.4$ & $12.6 \pm 2$ & 0.2 \\
\hline $\mathrm{HC}(10 \mu \mathrm{M})$ & 0.1 & 0.1 & 0.3 & 0.1 \\
\hline $\mathrm{II}-4+\mathrm{HC}$ & $32 \pm 3.8$ & $1.4 \pm 0.2$ & $35 \pm 4.1$ & 0.1 \\
\hline
\end{tabular}

* The monocyte-depleted cells contained no detectable $\mathrm{MO}_{2}$-positive cells.

₹ These cultures contained $1.5 \times 10^{6}$ monocyte-depleted PBMCs $+0.3 \times 10^{6}$ adherent cells; the adherent cells contained $82 \%$

$\mathrm{MO}_{2}$-positive cells, $5 \% \mathrm{CD} 20$-positive cells, and 1\% CD3-positive cells. ${ }^{8}$ These cells were cultured at $1.5 \times 10^{6}$ cells $/ \mathrm{ml}$. Identical results were obtained in three additional experiments. 


\begin{tabular}{|c|c|c|c|c|c|}
\hline \multirow{2}{*}{$\begin{array}{l}\text { Cells in } \\
\text { culture }\end{array}$} & \multirow{2}{*}{$\begin{array}{l}\text { Added to } \\
\text { cultures }\end{array}$} & \multicolumn{4}{|c|}{$\operatorname{lgE}(\mathrm{ng} / \mathrm{ml})$} \\
\hline & & Expt. 1 & Expt. 2 & Expt. 3 & Expt. 4 \\
\hline & & \multicolumn{4}{|c|}{$n g / m l$} \\
\hline & - & 0.4 & 0.4 & & 0.5 \\
\hline \multirow[t]{2}{*}{ PBMCs } & II-4 & 26.0 & 5.6 & ND & 5.8 \\
\hline & $\mathrm{IL}-4+\mathrm{HC}^{\S}$ & 43.0 & 10.6 & & 26.0 \\
\hline T cell-depleted & - & 0.3 & 0.2 & 0.6 & 2.3 \\
\hline \multirow[t]{2}{*}{ PBMCs* } & IL-4 & 0.3 & 0.2 & 0.8 & 2.1 \\
\hline & $\mathrm{IL}-4+\mathrm{HC}$ & 40.0 & 50.0 & 31.0 & 14.0 \\
\hline T cell-depleted & - & & & 0.5 & 0.3 \\
\hline \multirow[t]{2}{*}{ PBMC $^{\ddagger}+T$ cells } & IL-4 & ND & ND & 16.0 & 12.9 \\
\hline & $\mathrm{IL}-4+\mathrm{HC}$ & & & 58.0 & 31.2 \\
\hline
\end{tabular}

* The T cell-depleted PBMCs contained no detectable CD3-positive cells. ${ }^{\ddagger}$ These cultures contained $1.5 \times 10^{6} \mathrm{~T}$ cells-depleted PBMCs and 0.6 $\times 10^{6} \mathrm{~T}$ cells. Shown are the mean values of triplicate cultures. ND, not done. $\$ 10 \mu \mathrm{M}$.

The IgE-potentiating activity of HC is monocyte dependent. Previous studies have indicated that monocytes are required for an optimal IgE response to IL-4 (23). The complete removal of monocytes from PBMCs (by a two-step procedure described in Methods) strongly reduces the IgE response to IL-4 and completely abrogates the IgE-potentiating activity of HC (Table I). Both are reconstituted by the addition of adherent cells to the monocyte-depleted PBMCs. Monocytes cannot be replaced by the culture supernatant of adherent cells (cultured for 24 or 48 $h$ in culture medium alone, or in the presence of either IL-4, $\mathrm{HC}(1$ or $10 \mu \mathrm{M})$ or of both IL-4 and HC) tested at concentrations ranging from $5 \%$ to $40 \%$ (not shown). The addition of either IL-1 $(0.5-5 \mathrm{ng} / \mathrm{ml})$, IL-6 $(50-300 \mathrm{U} / \mathrm{ml})$ or a combination of both also fails to restore the IgE-potentiating effect of $\mathrm{HC}$ on monocyte-depleted PBMCs (not shown).

Table III. Effect of Cyclosporine A on the IgE Response of $B$ Cells Co-stimulated with $\mathrm{II}-4$ and $\mathrm{HC}$

\begin{tabular}{|c|c|c|c|}
\hline & \multicolumn{3}{|c|}{ IgE in cells in culture } \\
\hline & Stimulants & B cells ${ }^{\ddagger}$ & $T+B$ cells \\
\hline & & \multicolumn{2}{|c|}{$n g / m l$} \\
\hline & - & 0.1 & 0.1 \\
\hline & IL-4 & 0.1 & $8 \pm 2$ \\
\hline \multirow[t]{5}{*}{ Expt. 1} & $\mathrm{IL}-4+\mathrm{CyA}^{\prime \prime}$ & 0.1 & $1 \pm 0.5$ \\
\hline & IL-4 + HC' & $20.2 \pm 1.4$ & $29 \pm 3$ \\
\hline & $\mathrm{IL}-4+\mathrm{HC}+\mathrm{CyA}$ & $17.6 \pm 0.9$ & $14 \pm 2.8$ \\
\hline & - & $3.3 \pm 0.5$ & $5.3 \pm 1.8$ \\
\hline & IL-4 & $2.2 \pm 0.4$ & $15.8 \pm 1.2$ \\
\hline \multirow[t]{3}{*}{ Expt. $2^{*}$} & $\mathrm{IL}-4+\mathrm{CyA}$ & $3.9 \pm 0.3$ & $3.1 \pm 0.4$ \\
\hline & IL-4 + HC & $14.4 \pm 0.9$ & $31.2 \pm 1.2$ \\
\hline & $\mathrm{IL}-4+\mathrm{HC}+\mathrm{CyA}$ & $12.4 \pm 1.5$ & $13.0 \pm 0.9$ \\
\hline
\end{tabular}

The two experiments are representative of a series of six.

* Allergic donor.

‡ Rigorously T cell-depleted PBMCs containing no detectable CD3-positive cells.

$1.5 \times 10^{6} \mathrm{~B}$ cells $+0.6 \times 10^{6} \mathrm{~T}$ cells.

"CyA, cyclosporine A (1 $\mu \mathrm{g} / \mathrm{ml})$.

' $10 \mu \mathrm{M}$.
$T$ lymphocytes are not required for the synthesis of $\operatorname{IgE}$ by lymphocytes costimulated with IL-4 and HC. As expected, rigorously T cell-depleted PBMCs do not synthesize IgE in response to IL-4 alone, whereas the same cells secrete large amounts of IgE in response to IL-4 and HC (Table II). Reconstitution with $\mathrm{T}$ cells restores the responsiveness to IL-4 and further increases the response to IL-4 and HC. The amplifying effect of $\mathrm{T}$ cells is completely abrogated by cyclosporine $\mathrm{A}$ ( Table III). It is of note that the ability of HC to support T cell-independent IgE synthesis may be observed with very low concentrations (1 nM) of HC (not shown).

As a first approach to analyze the permissive effect of $\mathrm{HC}$ on the synthesis of IgE by T cell-depleted PBMCs, we have

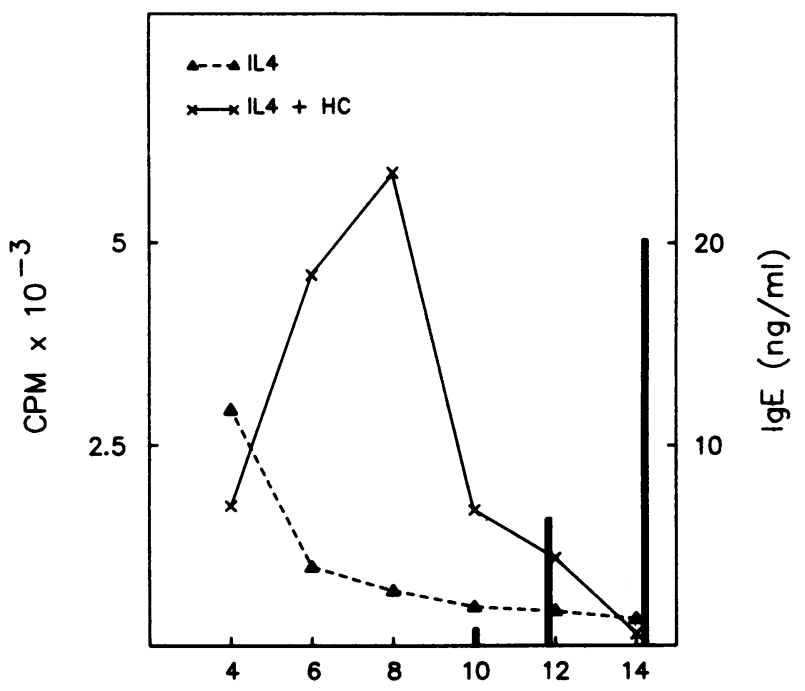

Figure 5. Kinetic study of $\left[{ }^{3} \mathrm{H}\right]$ thymidine incorporation and IgE secretion (solid bars) by T cell-depleted PBMCs cultured in the presence of IL-4, or of IL-4 and HC $(10 \mu \mathrm{M})$. There was no IgE in the cultures stimulated with IL-4 alone. This experiment was repeated four times with similar results. Note that, the $\left[{ }^{3} \mathrm{H}\right]$ thymidine uptake by IL-4-stimulated cells at day 4 is not different from that of either IL-4 and HC-stimulated cells or of control unstimulated cells. This was determined by statistical analysis of the pooled data from five experiments. 
examined the effect of HC on the proliferation of these cells. As seen (Fig. 5) HC significantly increases the $\left[{ }^{3} \mathrm{H}\right]$ thymidine uptake by the IL-4-stimulated cultures and this occurs before the onset of the IgE secretion. Using a two-stage culture system, we have next shown that IL-4 and HC must be present at the same time in order to induce IgE synthesis by $T$ cell-depleted PBMCs. In these assays, cells are first incubated for $7 \mathrm{~d}$ in the presence of either IL- 4 alone or IL- 4 and HC, washed, and cultured for another week (in the absence of IL-4) with or without HC. The results, contrasting with those observed on unfractionated PBMCs, clearly indicate that: $(a) \mathrm{IgE}$ is produced only when $\mathrm{HC}$ is present together with IL-4 during the primary cultures; (b) HC has no effect in the secondary cultures. For example in one (out of four) such experiment, the presence of both IL- 4 and $\mathrm{HC}$ in the primary cultures, induced the synthesis of $160 \pm 2 \mathrm{mg} / \mathrm{ml}$ of IgE in the secondary culture (irrespective of the presence of $\mathrm{HC}$ in the secondary culture). No IgE was detected in the secondary cultures when IL-4 was used alone in the primary cultures even when $\mathrm{HC}$ was added to the secondary cultures.

\section{Discussion}

It was recently reported that GCs increase the in vivo production of IL-4 and suppress that of IL-2; most interestingly this was observed with pharmacological as well as with physiological levels of GCs (24). The present study indicates that GCs markedly increase the synthesis of IgE by human lymphocytes cultured in the presence of IL-4. The significance of these two observations is twofold. First, they explain why the treatment of allergic patients with GCs does not suppress, and may even increase, their IgE antibody production (9-11). Secondly, they suggest that stress may favor the production of IgE. Hence, these findings probably explain the significant and transient elevation of serum IgE levels after myocardial infarction (25). This may also account for earlier observations in rodents that the magnitude of the IgE antibody response is temporally related to diurnal variation in endogenous steroid production (26). Two observations indicate that the effect of hydrocortisone on IgE synthesis is GC specific and most likely mediated by the HC-GC receptor complex. First, the steroid sex hormones have no influence on the IL-4-induced synthesis of IgE. This finding is of interest since it is known that serum IgE levels are influenced by age and sex $(27,28)$. Secondly, the IgE-potentiating activity of $\mathrm{HC}$ is inhibited by RU38486, a potent steroid hormone antagonist (29). The augmenting effect of $\mathrm{HC}$ on IgE synthesis by IL-4-stimulated cells is not isotype-specific, and moreover in the absence of IL-4, HC does not induce IgE synthesis whereas it increases the production of the other isotypes. The latter phenomenon has been extensively analyzed and shown to involve both cellular interactions between monocytes, $\mathrm{CD}^{+} \mathrm{T}$ cells and $\mathrm{B}$ lymphocytes as well as the release of $\mathrm{T}$ cell-derived soluble factors induced by $\operatorname{GCs}(30,31)$.

The mechanisms leading to the synthesis of IgE after the addition of IL- 4 to cultures of human PBMCs have been extensively analyzed. Briefly, IL-4 triggers cognate interactions between $T$ and $B$ cells, as a result of which B cells are primed to respond to soluble factors including IL-4 itself as well as endogenous IL-2, IL-6, and the low molecular weight B-cell growth factor $(23,32-35)$. Another important mechanism is the IL-4induced suppression of the production of natural antagonists of IgE synthesis such as $\mathrm{PGE}_{2}$ and $\operatorname{IFN}-\gamma(36,37)$. The present study further indicates that IL-4 needs to be present only dur- ing the first 4-5 $\mathrm{d}$ of the 12-d culture in order to elicit the synthesis of IgE which is most apparent at the end of the culture period. Moreover, the results show that $\mathrm{HC}$ potentiates the IgE response by acting both in the early (IL-4 dependent) and in the late stage (IL-4 independent) of the IL-4-driven stimulation of PBMCs. This indicates that, as expected from the ubiquity of GC receptors (38), $\mathrm{HC}$ acts at multiple steps of the IgE response to IL-4. As a first approach to analyze the IgE-potentiating effect of $\mathrm{HC}$ we have examined whether it may be explained by (a) the inhibition of IFN- $\gamma$ production; $(b)$ a change in the expression of Fc $\epsilon$ RII, and $(c)$ an alteration of the cellular interactions required to induce IgE synthesis by IL-4-stimulated PBMCs. To our knowledge, IFN- $\gamma$, IFN- $\alpha$, and $\mathrm{PGE}_{2}$ are the only known natural antagonists of the IL-4-induced synthesis of IgE (22). The inhibitory effect of GCs on the production of IFN- $\gamma$ and of PGs are well known whereas the influence of GCs on IFN- $\alpha$ production has not been reported $(39,40)$. Since IL-4 by itself strongly inhibits IFN- $\gamma(36)$ and $\mathrm{PGE}_{2}$ (37) production, it is unlikely that a major mechanism accounting for the IgE-potentiating effect of $\mathrm{HC}$ resides in the suppression of the small residual endogenous production of these agents. Indeed, HC markedly increases the synthesis of IgE by IL-4-stimulated neonatal lymphocytes in the absence of endogenous production of IFN- $\gamma$.

FceRII and its soluble fragments were reported to play a role in the synthesis of human IgE by IL-4-stimulated lymphocytes and by unstimulated lymphocytes from allergic donors $(18,20,21,41)$. The present results indicate that GCs reduce the expression of FceRII and the subsequent release of Fc $\in$ RIIsoluble fragments (IgE-BFs) by IL-4-stimulated PBMCs. These data are in agreement with earlier studies on the expression of FceRII by the U937 macrophage cell line (42). At optimal concentrations for IgE potentiation (1-10 $\mu \mathrm{M}) \mathrm{HC}$ suppresses the release of IgE-BFs by only 40-70\%. Most importantly, the IgE response to IL-4 and HC is dependent upon the expression of FceRII inasmuch as it is suppressed almost completely by anti-FceRII MAb. All the previous studies on the enhancing effect of GCs on the Ig production by human lymphocytes concur to indicate that it is strictly dependent upon the presence of monocytes $(43,44)$. The present results further suggest that a direct cell-cell contact between lymphocytes and monocytes is required in order to observe the IgE-potentiating effect of GCs. Indeed, monocytes cannot be replaced by monocyte-derived soluble factors nor by a cocktail of IL-1 and IL-6. An intimate contact between lymphocytes and monocytes was shown to be necessary for the induction of $(a)$ Ig synthesis by PBMCs in response to GCs (43) and $(b)$ the synthesis of IgE by monoclonal B cells from CLL patients in response to IL-4 and HC (M. Sarfati, G. Delespesse, and M. Rulio, manuscript submitted for publication).

The addition of IL4 to highly purified resting B cells is not sufficient to induce IgE secretion nor class switching to IgE, unless additional activation signals like lipopolysaccharides (LPS) for mouse lymphocytes or Epstein-Barr virus (EBV) for human cells are delivered to the cells $(45,46)$. Hence, B cell activation and proliferation is required for the IL-4-induced isotype switching and for the transformation of precursor $B$ cells into Ig-producing cells (47). When unfractionated PBMC are cultured with IL-4, the B cell activation signals are delivered by the $\mathrm{T}$ cells $(32-34)$. We here report that after rigorous depletion of $T$ cells, a strong IgE response is induced by costimulation with IL-4 and GCs, even when the latter are employed at physiological concentrations ( $10 \mathrm{nM}$ hydrocortisone). Since 
GCs are known to inhibit the proliferation of both B and T lymphocytes, it was important to examine whether the IL-4 and HC-induced synthesis of IgE by T cell-depleted PBMCs was accompanied by a wave of cellular proliferation. The data clearly indicate that $\mathrm{HC}$ induces a modest but significant increase of DNA synthesis by the IL-4-stimulated T cell-depleted PBMCs. This effect spans from days 6 to 10 and precedes the secretion of IgE which is first detectable at day 10 . The enhancing effect of GCs on DNA synthesis by IL-4-stimulated cells appears to be rather unique since GCs were shown to inhibit the proliferative response of B cells to various stimulants (1). However, more recent studies have shown that CGs interfere mainly with the early rather than with the late stages of B cell activation (4). In contrast to the present observations, Emilie et al. $(44,48)$ reported that the enhancing activity of GCs on the IgM/IgG production by Staphylococcus aureus Cowan I and IL-2 activated human T cell-depleted PBMCs was accompanied by a significant albeit incomplete inhibition of DNA synthesis.

Unlike unfractionated PBMCs, T cell-depleted mononuclear cells must be in contact with both IL-4 and HC, at least for $48 \mathrm{~h}$, in order to synthesize IgE. Hence, in the two-stage cultures, HC must be present together with IL-4 during the primary cultures, and moreover addition of $\mathrm{HC}$ to the secondary cultures has no effect. The cellular and the molecular mechanisms whereby HC and IL-4 stimulate T cell-depleted PBMC to synthesize IgE are currently analyzed in more detail. Since IL-4 is capable to induce a T cell-independent synthesis of IgE in the presence of physiological concentrations of $\mathrm{HC}$, it is possible that this mechanism may also operate in vivo. It may be postulated that during stress, which increases the secretion of cortisol and favors the production of IL-4 (24), bystander B cells (that are not involved in MHC-restricted interactions with $T$ cells) may be induced to differentiate into IgE-producing cells. Finally, it is worth noting that the IgE response of $\mathrm{T}$ celldepleted PBMCs may be further increased by the addition of $T$ cells. The amplifying effect of $T$ cells is abrogated by cyclosporine A, suggesting that it is mediated by $\mathrm{T}$ cell-derived lymphokines rather than by direct cell-cell interactions between $\mathrm{T}$ and B lymphocytes. Supporting this view are the recent observations indicating that IL-2 and T cell-derived low molecular weight $B$ cell growth factor play an important role in the IL-4induced IgE response (34).

\section{Acknowledgments}

We thank Mrs. Norma Del Bosco for her excellent secretarial assistance.

This work was supported by a Medical Research Council (MRC) grant. G. Delespesse is a Research Associate of the MRC, M. Sarfati is a Scholar of the MRC.

\section{References}

1. Cupps, T. R., and A. S. Fauci. 1982. Corticosteroid-mediated immunoregulation in man. Immunol. Rev. 65:133-159.

2. Schleimer, R. P. 1990. Effects of glucocorticoids on inflammatory cells relevant to their therapeutic applications in asthma. Am. Rev. Respir. Dis. 141:559-569.

3. Dupont, E. 1988. Immunological actions of corticoids and cyclosporine A. Curr. Opin. Immunol. 1:253-256.

4. Cupps, T. R., T. L. Gerrard, R. J. Falkoff, G. Whalen, and A. S. Fauci. 1985. Effects of in vitro corticosteroids on B cell activation, proliferation, and differentiation. J. Clin. Invest. 75:754-761.
5. Fauci, A. S., K. R. Pratt, and G. Whalen. 1977. Activation of human B lymphocytes. IV. Regulating effects of corticosteroids on the triggering signal in the plaque-forming response of human peripheral blood B lymphocytes to polyclonal activation. J. Immunol. 119:598-603.

6. Cooper, D. A., M. Duckett, V. Petts, and R. Penny. 1979. Corticosteroid enhancement of immunoglobulin synthesis by pokeweed mitogen-stimulated human lymphocytes. Clin. Exp. Immunol. 37:145-151.

7. Grayson, J., N. J. Dooley, I. R. Koski, and R. M. Blease. 1981. Immunoglobulin production induced in vitro by glucocorticoid hormones: $\mathrm{T}$ cell-dependent stimulation of immunoglobulin production without B cell proliferation in cultures of human peripheral blood. J. Clin. Invest. 68:1539-1547.

8. Wira, C. R., C. P. Sandoe, and M. G. Steele. 1990. Glucocorticoid regulation of the humoral immune system I. In vivo effects of dexamethasone on IgA and IgG in serum and at mucosal surfaces. J. Immunol. 144:142-146.

9. Settipane, G. A., R. K. Pudupakkam, and J. H. McGowan. 1978. Corticosteroid effect on immunoglobulins. J. Allergy Clin. Immunol. 62:162-171.

10. Johansson, S. G. O., and L. Juhlin. 1970. Immunoglobulin E in "healed" atopic dermatitis and after treatment with corticosteroids and azathioprine. Br. J. Dermatol. 82:10-13.

11. Henderson, L. L., J. B. Larson, and G. J. Gleich. 1973. Effect of corticosteroids on seasonal increases in IgE antibody. J. Allergy Clin. Immunol. 52:352357.

12. Del Prete, G. F., D. Vercelli, A. Tiri, E. Maggi, O. Rossi, S. Romagnani, and M. Ricci. 1987. Effect of in vitro irradiation and cell cycle-inhibitory drugs on the spontaneous human IgE synthesis in vitro. J. Allergy Clin. Immunol. 79:69-77.

13. Ray, A., Z. Hemady, and R. E. Rocklin. 1987. Glucocorticoid-induced enhancement of IgE synthesis. In New England Regional Allergy Proceedings. Volume 13. 81-84.

14. Sarfati, M., H. Luo, and G. Delespesse. 1989. IgE synthesis by chronic lymphocytic leukemia cells. J. Exp. Med. 170:1775-1780.

15. Rector, E., T. Nakajima, C. Rocha, A. H. Sehon, and G. Delespesse. 1985. Detection and characterization of monoclonal antibodies specific to IgE receptors on human lymphocytes by flow cytometry. Immunology. 55:481-488.

16. Delespesse, G., K. Wagner, H. Luo, V. Brinkmann, E. Kilchherr, and C. Heusser. 1989. The spontaneous production of IgE by lymphocytes from allergic donors: the ongoing IgE synthesis of lymphocytes from atopic individual is IL4-independent. Proceedings of the 7th International Congress on Immunology, Berlin. Gustav Fischer, Stuttgart. A:75.

17. Thiele, D. L., and P. E. Lipsky. 1985. Modulation of human natural killer cell function by L-leucine methyl ester: monocyte-dependent depletion from human peripheral blood mononuclear cells. J. Immunol. 134:786.

18. Sarfati, M., E. Rector, K. Wong, M. Rubio-Trujillo, A. H. Sehon, and G. Delespesse. 1984. In vitro synthesis of IgE by human lymphocytes. II. Enhancement of the spontaneous IgE synthesis by IgE-binding factors secreted by RPMI 8866 lymphoblastoid B cells. Immunology. 53:197-205.

19. Sarfati, M., T. Nutman, C. Fonteyn, and G. Delespesse. 1986. Presence of antigenic determinants common to $\mathrm{Fc}$ IgE receptors on human macrophages, $\mathrm{T}$ and $B$ lymphocytes and IgE-binding factors. Immunology. 59:569-576.

20. Sarfati, M., and G. Delespesse. 1988. Possible role of human lymphocyte receptor for IgE (CD23) or its soluble fragments in the in vitro synthesis of human IgE. J. Immunol. 141:2195-2199.

21. Pène, J., I. Chrétien, F. Rousset, F. Brière, J. Y. Bonnefoy, and J. E. deVries. 1989. Modulation of IL4-induced human IgE production in vitro by IFN- $\gamma$ and IL5; the role of soluble CD23 (s-CD23). J. Cell. Biochem. 39:253-264.

22. Pene, J., F. Rousset, F. Brière, I. Chrétien, J. Y. Bonnefoy, H. Spits, T. Yokota, N. Arai, K. Arai, J. Banchereau, et al. 1988. IgE production by normal human lymphocytes is induced by interleukin-4 and suppressed by interferon $\gamma$ and $\alpha$ and prostaglandin $\mathrm{E}_{2}$. Proc. Natl. Acad. Sci. USA. 85:6880-6884.

23. Vercelli, D., H. H. Jabara, K. Arai, T. Yokota, and R. S. Geha. 1989. Endogenous interleukin-6 plays an obligatory role in interleukin-4-dependent human IgE synthesis. Eur. J. Immunol. 19:1419-1424.

24. Daynes, R. A., and B. A. Araneo. 1989. Contrasting effects of glucocorticoids on the capacity of $\mathrm{T}$ cells to produce the growth factors interleukin 2 and interleukin 4. Eur. Immunol. 19:2319-2325.

25. Szczklik, A., K. Sladek, A. Szczerba, and J. Dropinski. 1988. Serum immunoglobulin $E$ response to myocardial infarction: pathophysiology and natural history. Circulation. 77:1245-1249.

26. Bargatze, R. F., and O. H. Katz. 1980. Allergic breakthrough, after antigen sensitization; height of IgE synthesis is temporally related to diurmal variation in endogenous steroid production. J. Immunol. 125:2306-2310.

27. Barbee, R. A., M. Halonen, M. Lebowitz and B. Burrows. 1981. Distribution of IgE in a community population sample: correlations with age, sex and allergen skin test reactivity. J. Allergy Clin. Immunol. 68:106-115.

28. Delespesse, G., B. Kennes, M. De Maubeuge, and A. Govaerts. 1977. IgE antibody production in aging. Scand. J. Immunol. 6:691-698.

29. Guiochon-Mantel, A., H. Loosfelt, T. Ragot, A. Bailly, M. Atger, M. Misrahi, M. Perricaude, and E. Milgrom. 1988. Receptors bound to antiprogestine form abortive complexes with hormone responsive elements. Nature (Lond.). 336:695-698. 
30. Orson, F. M., J. Grayson, S. Pike, V. De Seau, and R. M. Blaese. 1983. T cell-replacing factor for glucocorticosteroid-induced immunoglobulin production: a unique steroid-dependent cytokine. J. Exp. Med. 158:1473-1481.

31. Orson, F. M., F. P. Flagge, and J. L. Cashaw. 1986. T cell replacing factor for steroids (TRF-S): a 40,000 dalton protein produced by a $\mathrm{T}^{+} \mathrm{T}$ cell. $\mathrm{J}$. Immunol. 137:578-584.

32. Vercelli, D., H. H. Jabara, K. I. Arai, and R. Geha. 1989. Induction of human IgE synthesis required interleukin-4 and T/B-cell interactions involving the T-cell receptor/CD23 complex and MHC class II antigens. J. Exp. Med. 169:1295-1307.

33. Maggi, E., G. F. Del Prete, P. Parronchi, A. Tiri, D. Macchia, P. Biswas, C. Simonelli, M. Ricci, and S. Romagnani. 1989. Role for T cells, IL2 and IL6 in the IL4-dependent in vitro human IgE synthesis. Immunology. 68:300-306.

34. Dekruyff, R. H., T. Rutner, J. S. Abrams, Jr., M. A. Palladino, and D. T. Umetsu. 1989. Induction of human IgE synthesis by $\mathrm{CD}^{+} \mathrm{T}$ cell clones-requirement for interleukin 4 and low molecular weight B cell growth factor. J. Exp. Med. 170:1472-1493.

35. Smeland, E. B., H. K. Blomhoff, S. Funderud, M. R. Shalaby, and T. Espevik. 1989. Interleukin 4 induces selective production of interleukin 6 from normal human B lymphocytes. J. Exp. Med. 170:1463-1468.

36. Peleman, R., C. Fargeas, J. P. Wu, and G. Delespesse. 1989. IL-4 suppresses the production of IFN- $\gamma$ by human lymphocytes. J. Exp. Med. 170:17511756.

37. Hart, P. H., G. F. Vitti, D. R. Burgess, G. A. Whitty, D. A. Picolli, and J. A. Hamilton. 1989. Potential antiinflammatory effects of interleukin 4: Sup pression of human monocyte tumor necrosis factor $\alpha$, interleukin 1 and postaglandin E2. Proc. Natl. Acad. Sci. USA. 86:3803-3807.

38. Gustafsson, J. A., J. Carlstedt-Duke, L. Poellinger, S. Okret, A. C. Wikstrom, M. Bronnegard, M. Gillner, Y. Dong, K. Fuxe, A. Cintra, et al. 1987 Biochemistry, molecular biology and physiology of the glucocorticoid receptor Endocr. Rev. 8:185-234.

39. Culpepper, J., and F. Lee. 1987. Glucocorticoid regulation of lymphokine production by murine $\mathrm{T}$ lymphocytes. In Molecular Cloning and Analysis of Lymphokines. D. R. Webb and D. V. Goeddel, editors. Lymphokines. 13:275289.

40. Danon, A., and G. Assouline. 1978. Inhibition of prostaglandin biosynthesis by corticosteroids requires RNA and protein synthesis. Nature (Lond.). 273:552-553.

41. Sarfati, M., E. Rector, M. Rubio-Trujillo, K. Wong, A. H. Sehon, and G. Delespesse. 1984. In vitro synthesis of human IgE III. IgE potentiating activity of culture supernatants from Epstein-Barr virus (EBV) transformed B cells. Immunology. 53:207-214.

42. Naray-Fejes-Toth, A., G. G. Cornwell, and P. M. Guyre. 1985. Glucocorticoids inhibit IgE receptor expression on the human monocyte cell line U937. Immunology. 56:359-366.

43. Orson, F. M., and C. A. Auzenne. 1988. Glucocorticosteroid-induced immunoglobulin production requires intimate contact between $B$ cells and monocytes. Cell. Immunol. 112:147-155.

44. Emilie, D., S. Karray, M. C. Crevon, A. Vasquez, and P. Galanaud. 1987. B cell differentiation and interleukin 2 (IL2): corticosteroids interact with monocytes to enhance the effect of IL2. Eur. J. Immunol. 17:1791-1795.

45. Rothman, P., S. Lutzker, W. Cook, R. Coffman, and F. W. Alt. 1988. Mitogen plus interleukin 4 induction of $\mathrm{C} \epsilon$ transcripts in B lymphoid cells. J. Exp. Med. 168:2385-2389.

46. Thyphoronitis, G., G. C. Tsokos, C. H. June, A. D. Levine, and F. D. Finkelman. 1989. IgE secretion by Epstein-Barr virus-infected purified human B lymphocytes is stimulated by interleukin 4 and suppressed by interferon- $\gamma$. Proc. Natl. Acad. Sci. USA. 86:5580-5584.

47. Jelinek, D. F., and P. E. Lipsky. 1985. The role of T cell factors in activation, cell cycle progression and differentiation of human B cells. J. Immunol. 134:1690-1697.

48. Emilie, D., M. C. Crevon, M. T. Auffredou, and P. Galanaud. 1988. Glucocorticosteroid-dependent synergy between interleukin 1 and interleukin 6 for human B lymphocyte differentiation. Eur. J. Immunol. 18:2043-2047. 